\title{
Improving the Quality of Learning in Primary Schools
}

\author{
Ernawati \\ SD Negeri 1 Banyuasin III \\ Email: ernawati7922@yahoo.com \\ Edi Harapan \\ Universitas PGRI Palembang, Indonesia \\ e-mail: ehara205@gmail.com \\ Nila Kesumawati \\ Universitas PGRI Palembang, Indonesia \\ e-mail: nilakesumawati@yahoo.com \\ Article History: Received on 1 November 2021, Revised on 2 January 2022 \\ Published on 23 January 2022
}

\begin{abstract}
The purpose of this study is to identify school principals improves the quality of primary schools. The study was conducted at SD Negeri 1 Banyuasin III. The research was qualitative. The subject of the research is teachers in SD Negeri 1 Banyuasin III. Data were collected by interviews and analyzed using triangulation. The result showed that not all teachers can perform the task in full because obstacles covid 19, the solution applied is maximizing available resources.
\end{abstract}

Keywords: Quality, Management, School Principal, Primary School

\section{A. Introduction}

Improvement, developing and improving the quality of learning in the schools needs synergy of all stakeholders school to support all effectively. Building education is difficult, it cannot develop itself without support from the other hand (Suharsaputra, 2018). School is an institution held formal learning process in order to achieve the purpose of learning.

The high quality of learning are influenced by the quality of the learning process conducted by teachers because teachers directly provides guidance and assistance to students in an effort to achieve educational objectives. As explained by Ekosusilo (2013) the principal is the center of leader who governs and manage activities. Hence, the school principal is vital to improve the performance of teachers to be more spirit and professional teaching and developing themselves in transferring knowledge to students. Improving the quality of learning closely related to the effort to enhance the maturity of professional teachers, and it will be able to anticipate the challenges in the educational world. According to Suharsaputra (2018) learning is the main business in schools, so what made will cause to exist, but it is actually a reflection of how the school organizations designed, how school culture developed, and management carried out and how leadership at school able to move all of the members of the organization in school. Mulyasa (2013) defines the principal lead role his agency with great progress on increasing school. This is because the principal controls the activities programmed directed, focused and success well. To realize the quality of learning, the government issued a Regulation No 19 
years 2005 on national education standards, which mentions the standards of process to achieve standard graduates.

The learning on a unit of education held interactive, inspiring, fun, challenge, motivate students to actively participate, as well as to provide adequate space for initiative, creativity, based on talent and ability, interest and the development of physical and psychological students. The principal acts like an existency of central figure in effecting the teachers and institution. The remembrance of primary education is the foundation for next education. Joko (2018) suggested that the principal play an important role in improving the quality of learning. Principal lead role his agency with great progress on increasing school.

It was because the job of principal in supervising the event which has been programmed to be directed, focused and success well.School principals also play an important role in the increase in the performance teachers to be more spirit and professional in teaching. A good reason for principal very fundamental that teachers have a very important role in determining the quality of teaching in which principal carried out.

Hence need to be thinking about and plan carefully in increasing the opportunities to study for students and improved the quality of the teachers. This indicates that teachers should take part as the manager of the teaching and learning process, act as facilitators who always try to create the organization of classes, the use of a method of teaching and the attitudes of the teacher characteristics in managing the teaching and learning process. Device such as school principals, the council of teachers, employees must be mutual support to cooperate. Therefore it can be said that an organization success or failure in achieving its objectives set is very much dependent on its ability to grow the climate of cooperation that could be easily move, existing human resources so can work effectively and efficiently (Soepandi, 2018).

There is a strong tendency to improve the quality of services in improving the quality of learning in schools, teachers who need to be coached and set back is capacity so that in turn can be used to direct the teachers to be a professional. One of competence that should be owned by principal is supervision competence. Competence supervision is appropriate with Regulation National Minister of Education 13 of 2007 in order to increase the professional academic, teachers carry out supervision academic using approach and follow up on the academic supervision to increase the professional teachers (Mulyasa, 2013).

To support the competence, principal should have knowledge and skill in planning, implementing and follow up as to improve the quality of school. To improve the quality of teachers, activities as principal through the service and training by giving opportunity to develop professionally (Suharsaputra, 2018).

Supervision is an activity done by the leader relating to the leadership in order to maintain the quality of products. It aimed to improve the quality and performance (Gusmiyati et al, 2021; Yusuf et al, 2021). With guidance and assistance, the quality of human resources will always can be maintained and increased (Rusyan, 2016).

In the process of supervision, supervisor can serve as a source of information, source of the idea, source of guidance in many ways in order to increase the capability of professional teacher. Supervision as coordination, principals must lead a number of teachers and school strff each of which has a duty and responsibility (Susmadiana et al, 2021; Devi et al, 2021). 
Volume 2 (3) 2021

E-ISSN: 2723-6919 P-ISSN: 2746-0827

Supervisor shall ensure that each teacher can keep their job well in a situation. Cooperative work as evaluation to know the ability of teachers will be trained to be evaluated. In addition through evaluation it will be known teacher capacity after getting assistance and training from the supervisor (Rusman, 2016). To reach the appropriateness and a good performance, school should be led by a principal quality knowledgeable extensive, school management have a cultural organization, work as well as having misfortune against all forms of problems, obstacles and difficulties in the work as a leader or a manager (Ahmad, 2013).

Suharsaputra (2018) said that school principal involvement and teachers in the development of the the school also encourage to use available resources efficient to reach the maximal result. Leadership for school principal is interesting to be learned as an effort to obtain good schools and quality. Further, Sahertian (2016) explained that principal as a supervisor have a responsibility to teacher capacity building in managing learning activities in schools and play significant roles for development and progress school. The principal must also supervise well and properly in accordance with appropriate approach.

According to information from the school principal, the process of execution in performing the task to determine the school as an institution to formulate vision, mission, the achievement of goals and strategies. Organize school in the sense of making the structure of the organization, set staff and assign a duty of each staff. Supervise, control all the staff got to guide and the school was limited visits classes and review a moment in day-to-day activities.

\section{B. Methods}

This study is qualitative, with a view to acquire understanding of deep its interpretation of the meaning of the phenomenon in the field. The subject of this research is the teacher in SD Negeri 1 Banyuasin III. Data were collected using interviews, observation and documentation. It was analysed using triangulation resources to test credibility. This is done until obtained a tendency data so that data could be considered a truth value (Sukmadinata, 2011; Sugiyono, 2015; Arikunto, 2010).

\section{Results and Discussion}

Based on findings the school principal in improving the quality of primary schools including (1) counseling the teachers, operator, schools and administrative staff, and giving directions for students to learn diligent although in covid-19 situation; (2) giving directions for teacher to plan learning the regulation, (3) counseling the teachers to implement learning; (4) made policy in establishing rules the division of teaching tasks teachers and staff; (5) building teachers to conduct an evaluation of learning. Besides development of the school principal in improving the quality of SD Negeri 1 Banyuasin III by giving teachers the training and prove it with certificate. This is proven when in the competence of teachers, they passed and having a certificate. The school principal trying to furnish infrastructure for diplomatic learning be better. The school principal trying to improve the school quality by sending the operator to a computer course. This was evident on the event was held by the department of education and culture district Banyuasin, that SD Negeri 1 Banyuasin III operators have the best schools. The development of school is proven in 2019/2020 accreditation "A“. 
Volume 2 (3) 2021

E-ISSN: 2723-6919 P-ISSN: 2746-0827

The obstacles in guidance of school principals in increase the quality of learning in SD Negeri 1 Banyuasin III is 1) not all teachers have linear discipline of sciences; 2) teachers who have the job sometimes are not carried out according to the stipulated terms; 3 ) the assignment of teachers sometimes has not yet been fully met, because of being busy with the house and any other reason. In addition 1) not all the teachers and education staff work in accordance with set; 2) handbook teachers were lacking, books were in the library is not complete; 3) trying to add visual aids which is less, such science kit, mathematics kit, religion kit; 4) scheduled activities for monthly meeting to evaluate the results of the education was not done properly, 5) scheduled extracurricular, scouting, sport, arts, and religious activities was not done effectively.

Solution done by school principals in the quality of learning 1) teachers rehabilitation through the scheduled meeting monthly; 2) giving directions to teachers to discharge their duties diligently; 3) provide guidance to teachers linear for their graduate education; 4) giving workshop, supervision when teaching. Then 1) providing coaching staff to the teacher and for implementing their duties diligently; 2) buy handbook teachers were lacking, increase book in the library; 3) adding the science, mathematics, and religion kit; 4) scheduled monthly meeting to evaluate result of education; 5) scheduled students activities such extracurricular of scouting sport, art, and religious; 6) gives a mandate to senior teachers to assist supervision directly; 2) ask teachers to submit the result of supervision; 7) ask reports from individual teachers in the performance of duties, and other administrative staff.

Solution made by the school principal in driving teachers are routinely provide guidance and call one by one to share problems, the pandemic covid 19 permanent teachers are required to attend the schools and given the lectures learning online and offline, and give quota to each teachers with the budget by the government to the teaching.

The results of this study supported by Yuliono (2018) the most prominent role of Augmented Reality was that it improved students' knowledge and understanding of the materials actually in pandemic era. Mardalena et al, (2020) also explain there is significant influence of professional teacher competence to teacher performance. There are also significant influence academic supervision and professional competency teachers toward teacher performance. This study strengthens the research conducted where training is able to increase the quality of learning in terms of professional teachers and teacher performance (Husni and Dafik, 2018).

\section{Conclusion}

This study concluded that the school principal in improving the quality of learning is done effectively, but still found obstacles not all teachers can perform the task because of Covid-19, and it should maximize the power of sources.

\section{E. Acknowledgement}

Thank to the Principal of SD Negeri 1 Banyuasin III, Rector Universitas PGRI Palembang, Director of Graduate Program and friends of graduate program educational management Universitas PGRI Palembang who have supported us to do this project. 


\section{References}

Ahmad, S. (2013). Ketahanmalangan Kepemimpinan Kepala Sekolah [Principal's Leadership Misfortune]. Yogyakarta: Pustaka Pelicha.

Arikunto, S. (2010). Prosedur Penelitian Suatu Pendekatan Praktek [Research Procedure A Practical Approach]. Jakarta: Rineka Cipta.

Devi, D., Harapan, E., \& Wardiah, D. (2021). The Implementation of Principal's Supervision in SD Negeri Tungkal Ilir Banyuasin (Teacher's Competency Development Study). Journal of Social Work and Science Education, 2(1), 60-68. https://doi.org/10.52690/jswse.v2i1.206

Ekosusilo. (2013). Kepemimpinan Kepala Sekolah [Principal Leadership]. Jakarta: Dian Pustaka.

Gusmiyati, G., Lian, B., \& Fitria, H. (2021). Principal's Supervision in Improving Teacher's Performance. Journal of Social Work and Science Education, 2(1), 83-94. https://doi.org/10.52690/jswse.v2i1.209

Husni, H., \& Dafik, Y. F. (2018). Management of Islamic Higher Education in the 4.0 Industrial Revolution. Educational Review: International Journal, 15(2).

Joko, M. (2018). Strategi Kepala Sekolah dalam Meningkatkan Mutu Guru di Sekolah Menengah Pertama (SMP) Negeri 1 Cawas Klaten [Principal's Strategy in Improving Teacher Quality at State Junior High School (SMP) 1 Cawas Klaten]. Jurnal Manajemen Pendidikan, 2(2) 144-160.

Mardalena., Arafat, Y., \& Fitria, H. (2020). Pengaruh Supervisi Akademik dan Kompetensi Profesional Guru terhadap Kinerja Guru di Sekolah Menengah Atas Negeri di Kecamatan Tanjung Raja [The Effect of Academic Supervision and Teacher Professional Competence on Teacher Performance in Public High Schools in Tanjung Raja District]. Jurnal Manajemen Pendidikan, 9(1), 104-114.

Mulyasa. (2013). Manajemen dan Kepemimpinan Kepala Sekolah [Principal Management and Leadership]. Jakarta: Bumi Aksara.

Regulation No 19 years 2005 on National Education Standards

Rusman. (2016). Guru dan Profesinya [Teacher and Profession]. Jakarta: Rineka Cipta.

Rusyan. (2016). Manajemen Peningkatan Kinerja Guru, Konsep Strategi dan Implementasi [Teacher Performance Improvement Management, Strategy Concept and Implementation]. Bandung: Remaja Rosdakarya.

Sahertian. (2016). Konsep Dasar dan Teknik Supervisi [Basic Concepts and Supervision Techniques]. Bandung: Remaja Rosdakarya. 
Soepandi. (2018). Supervisi dan Administrasi di Sekolah [Supervision and Administration at School]. Jakarta: Raja Graffindo Persada.

Sugiyono. (2015). Metode Penelitian Pendidikan, Pendekatan Kuantitatif, Kualitatif dan $R$ \& D [Educational Research Methods, Quantitative, Qualitative and R\&D Approaches]. Bandung: Alfabeta.

Suharsaputra. (2018). Supervisi Pendidikan (Pendekatan Sistem Berbasis Kinerja) [Education Supervision (Performance Based Systems Approach)]. Bandung: Refika Aditama.

Sukmadinata, N. S. (2011). Metode Penelitian Pendidikan [Educational Research Methods]. Bandung: Remaja Rosdakarya.

Susmadiana, S., Lian, B., \& Puspita, Y. (2021). The Effect of Managerial Supervision and Work Motivation on Improving Principal's Performance. Journal of Social Work and Science Education, 2(2), 181-187. https://doi.org/10.52690/jswse.v2i2.248

Yuliono, T., \& Rintayati, P. (2018). The promising roles of augmented reality in educational setting: A review of the literature. International Journal of Educational Methodology, 4(3), 125-132.

Yusuf, M., Fitria, H., \& Mulyadi, M. (2021). The Influence of Teacher's Supervision and Professionalism on Teacher's Performance. Journal of Social Work and Science Education, 1(3), 234-240. https://doi.org/10.52690/jswse.v1i3.110 